\title{
COMMENTARY
}

\section{A true surgical pioneer}

\author{
Ian Davis, MD, FRCSC
}

See related article on page 407.

Can Urol Assoc J 2010;4(6):413

would like to congratulate and thank the authors for contributing what I believe to be the first significant paper

on the history of urology published in the Canadian Urological Association Journal. ${ }^{1}$ The relatively unknown Dr. Abraham Groves is an excellent choice.

Dr. Groves was a true surgical pioneer (Fig. 1). With his early adoption of the concept of asepsis and his remarkable comprehension of surgical principles, he was able to safely perform procedures unavailable in major centres. This is quite remarkable when he really had only 6 months of surgical training. In his time, a surgical apprenticeship usually involved just watching the professor and accepting his word as dogma. A lot has changed!

Dr. Groves did publish a number of articles on his accomplishments, but only in local journals. As a result few people know of his accomplishments. It is truly unfortunate that he did not work in a more academic environment where his knowledge would have been better recognized and disseminated; if so, more people could have learned from his skills.

Dr. Groves could easily be considered the Father of Canadian Urology.

Historian Emeritus, Canadian Urological Association, Hamilton, ON

Competing interests: None declared.

This paper has been peer-reviewed.

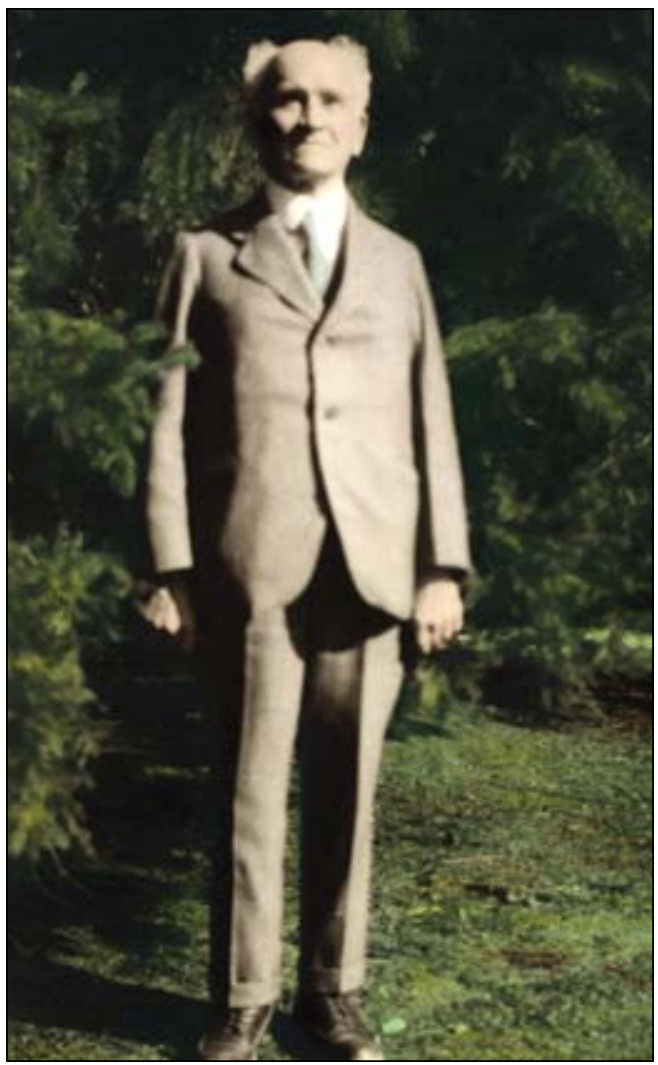

Fig. 1. Dr. Abraham Groves, circa 1931 (Wellington County Museum and Archives, ph 11728).

\section{Reference}

1. Caumartin Y, McAlister VC, Luke PPW. A pioneer of urologic surgery from a small town in Ontario, Canada: A tribute to Abraham Groves (1847-1935). Can Urol Assoc J 2010;6:407-12.

Correspondence: Dr. Ian Davis, Clinical Assistant Professor, Department of Surgery, 662 Concession St., Hamilton, ON L8V 1B8; fax: (905) 574-5234; iandavisurol@hotmail.com 